\title{
Lindsay Fitzharris, Rzeźnicy i lekarze. Makabryczny świat medycyny i rewolucja Josepha Listera, przekł. Łukasz Müller, "ZNAK", Kraków 2018, ss. 318 (rec. Maria J. Turos)
}

...czy na pewno pierwszy był James Syme?

- Czyli co wyszło z napisania recenzji

Warszawski Uniwersytet Medyczny

Miejsca, gdzie - jak to się mówi kolokwialnie - „wpadają w oczy” interesujące pozycje książkowe, jest bez liku. Tak też było i tym razem, zauważyłam w księgarni mieszczącej się na warszawskim dworcu najnowszą publikację Lindsley Fitzharris Rzeźnicy i lekarze ${ }^{1}$ z pięknym podtytułem Makabryczny świat medycyny i rewolucja Josepha Listera. Jest to książka dość obszerna, licząca 318 stron, z czego 38 zajmują przypisy ${ }^{2}$ odnoszące się do każdego $\mathrm{z}$ jedenastu rozdziałów poprzedzonych prologiem, a zakończonych epilogiem. Z notki biograficznej zamieszczonej na czwartej stronie okładki dowiedziałam się, że autorka jest doktorem historii nauki i medycyny, studia ukończyła w Oksfordzie, oczywiście prowadzi swoją stronę internetową ${ }^{3}$ i ma własny, cieszący się popularnością kanał na YouTube ${ }^{4}$. Prezentowana pozycja zebrała wiele przychylnych ocen ze strony prasy, w tym m.in. „Guardiana”, oraz została wyróżniona nagrodą „Wilson Prize for Literary Science Writing"'. Czyli rekomendacje najlepsze z możliwych. Tu walor pracy podnosi jeszcze obfita bibliografia, co już sytuuje książkę powyżej zwykłej beletrystyki, czyniąc z niej dzieło o charakterze popularnonaukowym. Jednak, pomimo takich i tym podobnych superlatywów, mam jeszcze zwyczaj, że przed nabyciem kolejnej pozycji przewracam kartki i staram się choć pobieżnie zapoznać z treścią. To

${ }^{1}$ L. Fitzharris, Rzeźnicy i lekarze. Makabryczny świat medycyny i rewolucja Josepha Listera, Kraków 2018.

2 Tamże, s. 280-318.

${ }^{3}$ https://www.drlindseyfitzharris.com [dostęp: 7.11.2018].

${ }^{4}$ https://www.youtube.com/user/UnderTheKnifeShow/feed [dostęp: 7.11.2018].

${ }^{5}$ L. Fitzharris, dz. cyt., czwarta strona okładki.

${ }^{6}$ Tamże. 
swego rodzaju amuse-bouche, jak zwykli mawiać Francuzi ${ }^{7}$, maleńka, smakowita przekąska, która podnosi apetyt, i zachęta do tego, co mnie czeka w czasie zasadniczej lektury.

Tak też było i tym razem. I chyba jakiś dobry duszek sprawił, że otworzyłam książkę na rozdziale V zatytułowanym Napoleon chirurgii, który - jak wynikało z pierwszego wersu - poświęcony był postaci wybitnego chirurga angielskiego, czy dokładniej szkockiego, gdyż przyszedł na świat 7 listopada 1799 r. w Edynburgu ${ }^{8}$ i tam praktycznie spędził większość swojego czynnego życia zawodowego, a mianowicie Jamesa Syme’a. Dalej już nie było niestety tak interesująco, mało tego, znów straciłam zupełnie ochotę na pisanie tekstu, jaki sobie pierwotnie zaplanowałam, a tym bardziej na nabycie książki. Otóż na str. $113 \mathrm{w}$ tymże samym rozdziale przeczytałam następujący wers: „sławę Syme’a należało w znacznej mierze przypisać jego przełomowemu pomysłowi amputowania nogi $\mathrm{w}$ stawie skokowo-goleniowym ${ }^{9}$. Pomijam już tłumaczenie, gdyż w takim tekście - oczywiście moim zdaniem - zdecydowanie lepiej zabrzmiałoby: „w stawie łączącym stopę z podudziem”, gdyż dokładnie anatomicznie stawy takie są dwa ${ }^{10}$, o czym czytelnik może nie wiedzieć, więc to - rzec można - drobnostka. Odłożyłam tom na regał, wyszłam z księgarni, lecz przez cały czas nie dawało mi spokoju pytanie: czy to on rzeczywiście przeprowadził po raz pierwszy tego rodzaju operację? Chirurgia przełomu XVIII i XIX w. i później, obfitująca w liczne konflikty zbrojne, była okresem wielu nowatorskich działań podejmowanych przez lekarzy, którzy zdobytej w ten sposób wiedzy zgodnie z zapisem ewangelicznym bynajmniej „nie chowali pod korzec"11.

Wypada zacząć od rodzinnego podwórka. Co na ten temat maja do powiedzenia Polacy? Technika tego rodzaju zabiegów, o których pisał Rafał Józef Czerwiakowski, jako o „odeymowaniu członków w stawach"12, musiała być znana zdecydowanie wcześniej. Zresztą ów „ojciec chirurgii polskiej” może służyć za przykład doskonałego ciągu myślowego, a zarazem międzyosobowego przekazu wiedzy

\footnotetext{
7 M. Karkosz, Rozkoszny smakuje Lyon, „Kuchnia” 2018, nr 4, s. 18.

${ }^{8}$ Tu za: H. Chisholm, James Syme, [w:] Encyclopaedia Britannica, T. XXVI, Cambridge 1911 (Ed. XI), s. 285.

${ }^{9}$ L. Fitzharris, dz. cyt., 113.

${ }^{10}$ A. Bochenek, M. Reicher, Anatomia człowieka. Anatomia ogólna. Kości, stawy i więzadła. Mięśnie, T. I, Warszawa 2009, s. 579.

${ }^{11}$ Tu za: Biblija Święta, London 1945, s. 4 (Mt. 5, 15).

12 Narzadu powszechnego opatrzenia chirurgicznego, część IV $₫ 1130-1343$ przez Rafała Czerwiakowskiego, w Krakowie 1816 roku, s. 225.
} 
w tym zakresie. Otóż w czasie, kiedy w latach 1777-1778 przebywał w Paryżu, jego nauczycielem i mistrzem był Raphael Sabatier - ten sam, który w 1803 r. był jednym z członków komisji promującej na stopień doktora chirurgii innego propagatora tej metody - Dominika Jeana Larreya. Ów wybitny chirurg i anatom francuski za życia nie publikował wiele $\mathrm{i}$ były to raczej prace dotyczace anatomii ${ }^{13}$. Chirurgii poświęcił zaplanowane na wiele tomów dzieło, które ukazywało się we fragmentach, poczynając od $1796 \mathrm{r}^{14}$, kiedy to wyszedł drukiem pierwszy tom. Drugi - choć numerowany jako trzeci - opuścił oficyne wydawniczą w $1800 \mathrm{r}^{15}$, a całość w jednej edycji (też sygnowanej jako tom trzeci) - w 1810 r., praktycznie tuż przed śmiercią autora ${ }^{16}$. W ,sekcji szóstej" ${ }^{17}$ tego tomu, gdyż w ten sposób został oznaczony rozdział, znaleźć można akapit noszący tytuł „o amputacji stopy przez wyłuszczenie jej z nogi" ${ }^{18}$, gdzie m.in. wspomniane jest nazwisko Fabrice'a de Hildena (był to niemiecki chirurg żyjący na przełomie XVI i XVII w., w latach 1560-1634, autor m.in. Observations chirurgiques wydanych w Genewie w 1649 r. ${ }^{19}$ ), jako jednego z chirurgów, którzy próbowali tej techniki operacyjnej. Dwanaście lat po śmierci Raphaela Sabatiera ukazało się obszerne czterotomowe dzieło De la medecine operatoire... ${ }^{20}$ opracowane i uzupełnione na podstawie zachowanych notatek przez Guillaume'a Dupuytrena, który znał osobiście tego wybitnego chirurga i przysłuchiwał się jego wykładom, oraz Louisa Josepha Sansona i Louisa-Jacques'a Begina. Amputacjom poświęcony jest tam obszerny rozdział, znów noszący nazwę „sekcji” ${ }^{21}$. Kończy on czwarty tom tego dzieła, i już w tytule akapitu użyte zostało określenie

${ }^{13} \mathrm{Tu}$ m.in. R. Sabatier, Traité complet d'anatomie, ou Description de toutes les parties du corps humain par M. Sabatier, Ed. Didot, Paris 1775, wznowione w 1798 r.

${ }^{14}$ R. Sabatier, De la Médecine opératoire ou des Opérations de chirugie qui se pratiquent le plus fréquemment. Tome premier, Ed. Didot le Jeune, Paris 1796.

${ }_{15} \mathrm{R}$. Sabatier, De la médecine opératoire, ou des opérations de chirurgie qui se pratiquent le plus fréquemment, Ed. Didot le Jeune, Paris 1800.

16 R. Sabatier zmarł 19 lipca 1811 r. Tu za: http://www.appl-lachaise.net/appl/article.php3?id_article=3296 9 [dostęp: 7.11.2018]. 432.

${ }_{17}$ De la medecine operatoire par m. Sabatier..., Ed. d'Huillier, Paris 1810, s. 349

${ }_{18}$ Tamże, s. 429-430.

19 Observations chirurgiques, Ed. Pierre Chouët, Geneve 1649. Tu za: Bibliotheque Nationale de France, http://data.bnf.fr/12516649/wilhelm_fabricius_hildanus/ [dostęp: 7.11.2018].

${ }^{20}$ R.B. Sabatier, De la médecine opératoire; nouvelle édition, faite sous les yeux de... Dupuytren par J.L. Sanson et L.J. Bégin, Ed. Bechet Jeune, Paris 1822-1824.

${ }^{21}$ M. Garnier, V. Delamare, Dictionnaire des termes techniques de medecine, Ed. Maloine, Paris 1974, s. 306. 
„wyłuszczenie w stawie”, gdyż tak można przetłumaczyć francuskie „desarticulation”22, jakie znaleźć można w obu tekstach. Zabiegi tego rodzaju w obrębie kończyny dolnej i stopy omówione zostały w podrozdziale „amputacje częściowe stopy” ${ }^{23}$ oraz w następnym noszącym tytuł „usuwanie przedniej części pierwszej i piątej kości śródstopia”24, gdzie zaprezentowano trzy różne sposoby postępowania, w tym modyfikację autorstwa samego Guillaume'a Dupuytrena ${ }^{25}$. W zasadniczym temacie wyszczególniono amputację $\mathrm{w}$ obrębie śródstopia wykonywaną metodą François Choparta ${ }^{26}$ - francuskiego chirurga z drugiej połowy XVIII w. ${ }^{27}$, wraz z późniejszymi zmianami techniki operacyjnej wprowadzonymi przez Pierre'a François Percy'ego - wybitnego lekarza epoki napoleońskiej ${ }^{28}$, którego sposób - o czym piszą autorzy - „znalazł wielu naśladowców”29, i wreszcie, najbardziej szczegółowo, metodę Jacques'a Lisfranca. Wykorzystano tu tekst jego niewielkiej objętościowo pracy Nouvelle méthode opératoire pour l'amputation partielle du pied dans son articulation tarso-metatarsienne ${ }^{30}$, do której jej autor, jeśli tak można napisać, materiały badawcze gromadził na polach bitew kampanii 1813 r. Akapit ten stanowi właśnie jedno $\mathrm{z}$ uzupełnień redakcyjnych.

Warto w tym miejscu zaznaczyć, że Jacques Lisfranc najprawdopodobniej prezentował swoją nową metodę operacyjną już wcześniej, na jednym z posiedzeń Instytutu Królewskiego, jednej z instytucji życia naukowego funkcjonującej we Francji po powrocie do władzy Burbonów. Wskazuje na to zachowany tekst wystąpienia z dnia 21 listopada 1814 r., na którym Jacques Lisfranc i J. DeChampesme (imię niestety nie jest znane) omówili metody wyłuszczenia w stawie ramieniowym $^{31}$.

${ }^{22}$ R.B. Sabatier, De la médecine opératoire ; nouvelle édition, faite sous les yeux de... Dupuytren par J.L. Sanson et L.J. Bégin..., s. 552.

${ }^{23}$ Tamże, s. 552-559.

${ }^{24}$ Tamże, s. 557.

${ }^{25}$ Tamże, s. 558.

${ }^{26}$ Tamże, s. 553.

${ }^{27}$ http://www.whonamedit.com/doctor.cfm/3269.html [dostęp: 4.11.2018].

${ }^{28}$ H. Ducoulombier, Un chirurgien de la Grande Armee. Le baron Pierre-François Percy, Ed. Teissedre, Paris 2004, wstęp br. paginacji.

${ }^{29}$ R.B. Sabatier, De la médecine opératoire nouvelle édition, faite sous les yeux de... Dupuytren par J.L. Sanson et L.J. Bégin..., dz. cyt., s. 553.

${ }_{30} \mathrm{~J}$. Lisfranc, Nouvelle méthode opératoire pour l'amputation partielle du pied dans son articulation tarso - metatarsienne, Ed. Gabon, Paris 1815.

${ }^{31} \mathrm{~J}$. Lisfranc, J. DeChampesme, Nouveau procédé opératoire pour l'amputation $d u$ bras dans son articulation scapulohumérale par J. Lisfranc de St-Martin et par J. de Champesme, Mémoire lu à la 1re classe de l'Institut Royal de France le 21 novembre 1814, suivi du Rapport fait par MM. les commissaires de la classe, Ed. Crochard, Paris 1815. 
Ale co jest jeszcze ciekawego. Opisując ogólnie techniki amputacji Raphael Sabatier często sięgał daleko w przeszłość, podając przy sposobach wykonywania tego typu operacji w obrębie uda prócz wzmiankowanego już Hildena (pisze to nazwisko w formie „Hidden”, ale nie można wykluczyć błędu przy odczytywaniu manuskryptu) m.in. technikę Lowdhama, który przeprowadził taki zabieg w 1679 r., następnie modyfikację Verduina z 1696 r. oraz Sabourina z 1702 r. $^{32}$ (tu nie podaje imion). Nawiązywał również do sposobów działania Huguesa Ravatona, które wprowadził w 1739 r., a także odnosił się pozytywnie do innych jego prac powstałych w latach $1750-1776^{33}$, w tym szczególnie Chirurgie d'armee... ${ }^{34}$ Sposoby działań chirurgicznych poprzedników były mu doskonale znane, cenił je i szanował, działając zgodnie z myślą polskiego noblisty Czesława Miłosza, że: „najbardziej ludzką z naszych czynności jest praca prządki, ponieważ nitki wysnute przez naszych poprzedników nie giną" 35 . W taki sam sposób przekazywał również swoją wiedzę licznym uczniom.

Wracajmy do Polski. W obszernej, liczącej w sumie siedem tomów wydanych drukiem pracy Narzadu powszechnego opatrzenia chirurgicznego ${ }^{36}$, która wyszła spod pióra Rafała Józefa Czerwiakowskiego, znaleźć można odpowiedni akapit liczący w sumie dziewięć stron (226-235) i podający, po wprowadzeniu omawiającym patofizjologię, w kolejnych paragrafach technikę amputacji w odniesieniu do kolejnych stawów. Bezpośrednio o zabiegu dokonywanym w śródstopiu można tam przeczytać następujący wers: „jeżeli poiedyńcze kości uszkodzone są w takim razie lepiej je wyjąć gdyż chory małego kawałka stopy może jeszcze użyć do chodu maiąc dobrze zrobiony i wypchany trzewik" ${ }^{37}$. Owszem Rafał Józef Czerwiakowski wzmiankuje, że na

${ }^{32}$ R.B. Sabatier, De la médecine opératoire; nouvelle édition, faite sous les yeux de... Dupuytren par J.L. Sanson et L.J. Bégin..., s. 497-498.

${ }^{33}$ Były to: Traité des playes d'armes à feu avec des observations sur différens genres de maladies, \& plusieurs méthodes nouvelles, tant pour les opérations de chirurgie que pour la réduction des fractures. Par M. Ravaton, Ed. Delaguette, Paris 1750 oraz Pratique moderne de la chirurgie, par M. Ravaton, chirurgien major de l'hôpital militaire de Landau, inspecteur des hôpitaux de Bretagne, chevalier de Saint-Roch \& pensionnaire du Roi; publiée et augmentée par M. Sue le Jeune, ancien prévôt du college de chirurgie, ancien professeur-démonstrateur d'anatomie \& de chirurgie à l'ecole pratique, chirurgien ordinaire de l'hôtel-de-ville, des académies de Montpellier, Rouen, Dijon, \&c. Avec figures en taille-douce, Ed. Vincent, Paris 1776.

${ }^{34} \mathrm{H}$. Ravaton, Chirurgie d'armee ou traite des plaies d'armes de feu et d'armes blanches, Ed. Didot le Jeune, Paris 1768.

${ }^{35}$ Tu za: G. Borkowska, Widzenia nad Zatoka San Francisco. Czesław Miłosz, „Tygodnik Powszechny" 2000, nr 32, s. 12.

${ }^{36}$ Narzadu powszechnego opatrzenia..., dz. cyt.

37 Tamże, s. 234. 
ogół wykonuje się wówczas amputację wyżej „na goleni w niejakiey odległości od kolana, aby operowany potem z lepszą dogodnością używać mógł szczudła" 38 , ale zarazem zwraca uwagę, że wszystko zależy tu od miejsca zranienia czy innego uszkodzenia kończyny i to przede wszystkim stanowi podstawę dla chirurga przy wyborze przez niego takiej, a nie innej techniki operacyjnej. Trudno tu pominąć i inną uwagę, jaką zamieścił w tekście, gdy dodaje, że: „w nowszych zaś czasach byli niektórzy Chirurgowie tego zdania, że amputacya w stawach nie iest niebespieczniejsza od innych, że nietyle bólu sprawuje, że przy niej ropienie iest mniejsze i rana prędzej się goi" ${ }^{39}$. Niestety, wspominając o chirurgach, nie podaje nic więcej. Któż to był? Można jedynie przypuszczać, iż stanowili oni grono jego paryskich przyjaciół i nauczycieli.

W tym samym czasie, gdy w Krakowie powstawał manuskrypt Rafała Józefa Czerwiakowskiego, w Wilnie ukazała się dwutomowa Chirurgia autorstwa Józefa Szymkiewicza ${ }^{40}$. Tam również w drugim tomie znaleźć można, co prawda niewielki, ale istotny akapit włączony do rozdziału XXXIX noszącego tytuł „Odeymowanie członków”41. Warto sięgnąć do niego, by przeczytać tam m.in.: ,jeżeli koście pojedynczo dłoni ręki lub podeszwy są zepsute nie wypada do tego całey ręki lub nogi amputować gdyż takowe koście można poiedyńczo wydobydź, ocalając resztę ciała"42.

O tego rodzaju zabiegu pisze również Józef Czekierski w swojej obszernej liczącej cztery tomy Chirurgii... ${ }^{43}$ Zagadnieniu temu poświęca kilka następujących po sobie paragrafów, poczynając od paragrafu 146 noszącego tytuł „O odjęciu członków w stawach”44. W kolejnych omawia zabiegi tego typu przeprowadzane w obrębie stawów kończyny górnej i dolnej. Paragraf 152, noszący tytuł „O odjęciu stopy ze stawu”45, poświęcony jest zabiegom przeprowadzanym w tej okolicy, przy czym już na wstępie można znaleźć informację, iż „tą operację od dawnych czasów uskuteczniano"46, następnie zaś jest wplecione

${ }^{38}$ Tamże.

39 Tamże, s. 226.

${ }^{40} \mathrm{~J}$. Szymkiewicz, Nauka chirurgii teoretyczney i praktyczney przez Szymkiewicza, Druk. Jóżefa Zawadzkiego, Wilno 1806.

${ }^{41}$ Tamże, s. 142-144.

${ }^{42}$ Tamże, s. 143.

43 J. Czekierski, Chirurgii..., t. I, W drukarni przy Nowolipiu, Warszawa 1817.

${ }^{44}$ Tamże, s. 236-237.

45 Tamże, s. 246.

${ }^{46}$ Tamże. 
w tekst nazwisko „Fabric v.Hidden”47, czyli tego samego chirurga, który został wymieniony przez Rapahaela Sabatiera - na którego znajomość tematu powołuje się też Józef Czekierski. Zaznacza przy tym, że „członki mogą bydź we wskazaniach zdarzających się z łatwością odięte"48. Odnośnie do zabiegu wykonywanego na kończynie dolnej rozróżnia działanie „śrzodkiem stopy”" stąd nie jest wykluczone, że znał technikę Choparta (amputacja w stawie poprzecznym stępu między kością skokową a łódkowatą) w wersji podanej w pierwszym wydaniu dzieła Raphaela Sabatiera, a być może zapoznał się z nią podczas kontaktów z francuskimi chirurgami, którzy pracowali w $1807 \mathrm{r}$. w lazaretach wojskowych na terenie Warszawy, oraz oddzielne dotyczące pojedynczych palców. Szczegółowo podaje też sposób wykonania cięcia, następnie uformowania kikuta przez pokrycie go

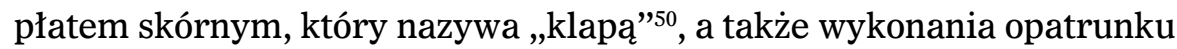
przy użyciu specjalnych „lepkich plastrów”

Technika wyłuszczania w stawach musiała być też znana Janowi Tomorowiczowi, autorowi Chirurgii obozowej ${ }^{52}$, tym bardziej że już we wstępie jako publikacje, z których korzystał, cytuje dzieła przede wszystkim Jamesa Williego, Józefa Szymkiewicza i Huguesa Ravatona $^{53}$. Wspomina o takim zabiegu tylko $\mathrm{w}$ odniesieniu do stawu barkowego, pisząc o „wyięciu ramienia ze stawu”,54, lecz trudno po tak małym, liczącym 116 stron dziełku spodziewać się precyzji wielotomowego opracowania.

Nad sposobem wykonywania tego rodzaju amputacji, która wyraźnie skracała czas zabiegu, co przed erą znieczulenia ogólnego grało niebagatelną rolę, pracował wzmiankowany już uczeń Raphaela Sabatiera, kolejny wybitny chirurg epoki napoleońskiej - Dominique Jean Larrey, który opublikował swoje czterotomowe Memoires ${ }^{55}$, a następnie pogłębił i rozwinął temat w Clinique Chirurgicale ${ }^{56}$.

47 Tamże.

${ }^{48}$ Tamże.

49 Tamże, s. 247.

${ }^{50}$ Tamże.

51 Tamże, s. 248.

${ }_{52}$ Chirurgia obozowa przez Tomorowicza sztabs-lekarza 7 putku piechoty liniowey Woyska Królestwa Polskiego, Druk. Zawadzki i Węcki, Warszawa 1816.

${ }_{53}$ Tamże, s. VIII.

${ }^{54}$ Tamże, s. 74.

55 D.J. Larrey, Memoires de chirurgie militaire et campagnes de D. J. Larrey, Ed. J. Smith, Paris 1812, t. I, II i III, t. IV - 1817.

56 J.D. Larrey, Clinique chirurgicale, exercée particulièrement dans les camps et les hôpitaux militaires, depuis 1792 jusqu'en 1829, Ed. Gabon, Paris 1829, późniejsze tomy Ed. Balliere, Paris 1832. 
Należy tu nadmienić, że technikę wyłuszczania w stawach, szczególnie dużych, jak barkowy czy biodrowy, doskonalił on przez całe swoje życie zawodowe. W odniesieniu do interesującego nas obszaru anatomicznego już w pierwszym tomie Memoires można znaleźć wzmiankę o przeprowadzeniu tego rodzaju zabiegu. Został on opisany jako „częściowa amputacja stopy w obrębie śródstopia między kośćmi stępu a śródstopiem"57, a wykonany został w 1793 r. albo w Moguncji, albo w najbliższej okolicy po jednej z bitew kampanii nad Renem, przy czym Larrey zaznaczył dalej w tekście, że przeprowadził kilkanaście podobnych operacji, natomiast na temat wyników miał przygotować oddzielne doniesienie. Ogólnie o wyłuszczeniach w stawach wspomina także w swojej dysertacji doktorskiej z $1803 \mathrm{r} .{ }^{58}$ Aby ułatwić sam sposób wykonywania tego rodzaju operacji w warunkach polowych, skonstruował specjalny instrument, który bardzo pięknie opisał Józef Peszke - w latach 80. XIX w. pełniący m.in. obowiązki bibliotekarza Towarzystwa Lekarskiego Warszawskiego - w tekście, który dołączył do biogramu tego wybitnego chirurga zamieszczonego w Wielkiej Encyklopedyi Illustrowanej ${ }^{59}$, gdzie wyraźnie zaznaczył, że „piłka nożowata”, gdyż taką nadał jej nazwę, znana była początkowo jako piłka Larreya, ale dość szybko zmieniła swoje miano na piłka Langebecka, i pod nim była powszechnie używana.

Czy James Syme mógł zapoznać się z tymi pracami? Oczywiście, pomińmy tu język polski, jako - że użyję współczesnego określenia - dość „niszowy”, lecz język francuski był jednak dość powszechnie znany nie tylko w kręgach arystokratycznych, ale także osób mających wyższe wykształcenie. Jeśli przyjąć, że w 1831 r. ukazała się książka Treatise of the excision of joint diseases ${ }^{60}$, kolejno omawiająca zabiegi amputacji w stawach, poczynając od barkowego ${ }^{61}$ (częściowej amputacji stopy oraz $\mathrm{w}$ obrębie stawu skokowego poświęca kolejno rozdział VIII ${ }^{62}$ oraz $\mathrm{X}^{63}$ ), pierwszy zabieg mógł przeprowadzić ok. 1825-1830 r. - z pewnością tak. $O$ tym zresztą sam pisze $\mathrm{w}$ rozdziale $\mathrm{X}$, gdzie jako jednego $\mathrm{z}$ autorów podobnej techniki operacyjnej wymienia

57 D.J. Larrey, Memoires de chirurgie..., t. I.

${ }_{58}$ D.J. Larrey, Dissertation sur les amputations des membres à la suite des coups de feu, Paris 1803.

59 Wielka Encyklopedia Powszechna Ilustrowana, serya I, t. XLI-II, Warszawa 1908/1909, s. 967.

${ }^{60} \mathrm{~J}$. Syme, Treatise of the excision of joint diseases, Sutherland and Knox, Edinburgh 1831.

${ }^{61}$ Tamże, s. 38-62.

${ }^{62}$ Tamże, s. $140-142$.

${ }^{63}$ Tamże, s. 146-158. 
Jacques'a Lisfranca (drugim z chirurgów jest „Hey z Leeds” ${ }^{64}$ ), cytuje również nazwisko Choparta ${ }^{65}$ oraz Langebecka z Getyngi ${ }^{66}$. Wspomina także Philiberta-Josepha Rouxa oraz jego pracę dotyczącą wyłuszczenia w stawie łokciowym, powstałą w $1812 \mathrm{r}^{67}$, cytowaną następnie w „Revue Medicale”68 w lutym 1830 r., która ukazała się w całości w Edynburgu ${ }^{69}$. W tymże samym „Revue Medicale” ukazał się kilka lat wcześniej (w 1823 r.) tekst Jaquesa Lisfranca, także poświęcony temu zagadnieniu ${ }^{70}$. Przypuszczalnie mógł być mu również znany zbiór tekstów tego autora obejmujący trzy artykuły, z których ostatni - Memoire sur le nouveau procede pour l'amputation dans les articulations des phalanges ${ }^{71}$ - dotyczył wyłuszczenia paliczków. Generalnie wyraża pogląd: „wydaje się to niezwykłe, iż ta operacja nie została dotychczas wprowadzona do brytyjskiej praktyki chirurgicznej"72.

Trochę też zaskakuje fakt, że autorka w rozdziale, gdzie tyle miejsca poświęca postaci Jamesa Syme'a, pisząc o działaniach tego chirurga, w przypisach, których jest aż 35, nie uwzględniła jego monografii poświęconej właśnie amputacjom, gdzie on sam wymienia swoich poprzedników, a nie można wykluczyć, iż także nauczycieli.

Tu na marginesie warto nadmienić, że na egzemplarzu tego niewielkiego dziełka znajdującym się w zbiorach „Royal College of Physicians” w Edynburgu znajduje się dość nieczytelny podpis „Calthorp (Catthorp) William"73, a notka bibliologiczna sytuuje tę pozycję $\mathrm{w}$ kategorii dzieł, które trafiły do zbiorów w pierwszej ćwiartce XIX w. ${ }^{74}$ W zbiorach tej samej biblioteki znajduje się również podobnie zakla-

${ }^{64}$ Tamże, s. 146.

65 Tamże.

${ }^{66}$ Tamże, s. 149.

${ }^{67}$ Była to dysertacja doktorska De la résection ou du retranchement de portions d'os malades, soit dans les articulations, soit hors des articulations : dissertation soutenue publiquement dans l'amphithéâtre de la Faculté de médecine de Paris, en présence des juges du concours, le [lundi 27 janvier] 1812, Ed. Migneret, Paryż 1812.

${ }_{68}$ Przypuszczalnie J. Syme’owi chodziło tu o ukazujący się od 1820 r. periodyk „Revue Medicale Historique et Philosophique”, którego wydawcą był Gabon (Paris 1820).

69 J. Syme, dz. cyt., s. 159.

${ }^{70} \mathrm{Tu}$ za: J. Lisfranc, Notice analytique sur les travaux de Lisfrancs, b.m.w. 1834, s. 4.

${ }^{71} \mathrm{~J}$. Lisfranc, Memoire sur de nouvelles applications du stéthoscope de M. le professeur Laennec: suivi d'un mémoir sur une nouvelle méthode de pratiquer la taille chez la femme...; et d'un mémoir sur un nouveau procédé pour l'amputation dans les articulations des phalanges, Ed. Gabon, Paris 1823.

72 J. Syme, dz. cyt., s. 148-149.

${ }^{73} \mathrm{~J}$. Lisfranc, Memoire sur de nouvelles..., dz. cyt., karta przedtytułowa.

${ }^{74} \mathrm{http}$ //catalogue.rcpe.ac.uk:8380/liberty/opac/search.do?=Lisfranc [dostęp: 4.11.2018]. 
syfikowana, wzmiankowana już uprzednio praca Jacques'a Lisfranca, poświęcona tej samej problematyce ${ }^{75}$.

Warto tutaj znów postawić pytanie, czy Syme zapoznał się z tekstami i innych autorów. Odpowiedź może brzmieć: przypuszczalnie tak. Wskazuje na to m.in. jedna z plansz zamieszczonych po tekście jego publikacji, gdzie zaprezentowana jest piłka Larreya ${ }^{76}$, niestety bez podania nazwiska konstruktora instrumentu, a jedynie $\mathrm{z}$ taką adnotacją: „piłka, która może być w pewnych okolicznościach użyteczna" "77. Ale na dziełach Larreya wydanych w Anglii kładła się negatywna opinia wyrażona przez tłumacza, a dotycząca całokształtu działań podejmowanych przez tego wybitnego chirurga. Jak pisze David Welling ${ }^{78}$, pogląd taki sformułowano już w pierwszej ćwierci XIX w., a u jego podstaw legła wypowiedź brytyjskiego chirurga o nazwisku Blackadder, który użył w niej zwrotu, że ten wybitny francuski chirurg „miał manię operowania”79. W swojej opinii odnosił się z pewnością do powszechnie dziś krytykowanego ${ }^{80}$ komentarza, który po opublikowaniu w 1815 r. na terenie Wielkiej Brytanii części notatek Larreya wyszedł spod pióra tłumacza Johna Walkera ${ }^{81}$.

Wypada teraz sięgnąć do dzieł chirurgów brytyjskich, a te przypuszczalnie były twórcy owej „nowatorskiej”82 jak zaznacza autorka książki, i co może sugerować sam tytuł rozdziału, metody operacyjnej, przynajmniej w ogólnych zarysach znane. Tu na pierwszy plan wysuwa się obszerne czterotomowe dzieło Benjamina Bella. Pierwsze wydanie ukazało się w Edynburgu w $1784 \mathrm{r}^{83}$, później zaś było wielokrotnie wznawiane, m.in. $\mathrm{w} 1796 \mathrm{r}^{84} \mathrm{~W}$ trzecim tomie znajduje się

75 J. Lisfranc, Nouvelle méthode opératoire..., dz. cyt.

${ }^{76} \mathrm{~J}$. Syme, dz. cyt., plansza $\mathrm{nr} 4$, br. paginacji.

77 Tamże, opis plansz, br. paginacji

${ }^{78}$ D.R. Welling, D.G. Burris, N.M. Rich, The influence of Dominique Jean Larrey on the art and science of amputations, „Journal of Vascular Surgery” 2010, vol. 52, nr 3 s. 793.

${ }^{79}$ O.H. Wangensteen, S.D. Wangensteen, The rise of surgery from empiric craft to scientific discipline, „Minneapolis University of Minnesota Press” 1978, s. 34-35.

${ }^{80}$ R. Debenedetti, Eloge de Jean - Dominique Larrey a l'occasion du bi - centenaire de sa naissance, „Bulletin de l'Academie de Medicine” 1966, nr 150, s. 488-506, s. 256 również R.G. Richardson, Larrey. What manner of Man, „Proc. Roy. Soc. Med.”, July 1977, vol. 70, s. 490-494.

${ }^{81}$ R.G. Richardson, Larrey: Surgeon to Napoleon's Guard, „J. Murray”, London 1974, s. 256.

${ }^{82}$ L. Fitzharris, dz. cyt., s. 113.

${ }^{83}$ B. Bell, A system of surgery, Ed. Ch. Elliot, Edinburgh 1784.

${ }^{84}$ B. Bell, A system of surgery, Ed. Bell \& Bradfute, Edinburgh 1796. Na karcie tytułowej zaznaczone „wydanie szóste powiększone i uzupełnione”. 
obszerny rozdział zatytułowany bardzo prosto „Amputacje”85. Prócz omówienia wskazań i zaprezentowania na planszach instrumentarium, jakie było pożądane do szybkiego i sprawnego przeprowadzenia zabiegu, w sekcji X - gdyż i on w ten sposób tytułuje poszczególne akapity, zajmuje się amputacjami w obrębie „stopy, palców u nogi” ${ }^{86}$ oraz dodatkowo jeszcze samych palców.

Stąd może nie licytujmy się dziś, kto był pierwszy. Jamesa Syme’a ktoś jednak tej techniki operacyjnej nauczył, gdzieś o tym przeczytał bądź w inny sposób ją poznał. No i miał trochę szczęścia, że później „ochrzczono” ów sposób postępowania właśnie jego mianem. Zwraca zresztą na to uwagę R.I. Harris w swoim obszernym tekście ${ }^{87}$ poświęconym technice amputacji według Syme'a, wymieniając tam m.in. Luciena B. Baudensa, który podobny sposób przeprowadzania zabiegu opisał w $1842 \mathrm{r}^{88}$, a także Mikołaja Pirogowa i wielu innych chirurgów, którzy wykonywali w latach 50. i 60. XIX w. amputacje w obrębie śródstopia, stosując przy tych operacjach własne metody postępowania bądź też modyfikując już znane.

Warto zatrzymać się przy postaci Luciena Baudensa. Otóż, na co wskazują ryciny ${ }^{89}$ zamieszczone w jego pracy, doskonalił i preferował technikę pozwalającą na protezowanie w sposób, jaki opisał Rafał Józef Czerwiakowski, a w tekście pierwszego rozdziału, noszącego zresztą tytuł „Historia”, cytuje cały szereg nazwisk swoich poprzedników, wśród nich też Benjamina Bella ${ }^{91}$. Wzmiankuje także, że Astley Paston Cooper temat ten pomija milczeniem, co nie powinno tak bardzo dziwić, gdyż głównym obszarem jego zainteresowań pozostawała raczej jama brzuszna i operacje przepuklin ${ }^{92}$, natomiast Samuel Cooper w swoim zasadniczym dziele The first lines of surgery. Being an elementary work for students, and a concise book of reference for practitioners ${ }^{93}$ poświęca mu niewiele uwagi, w rozdziale 61 omawiając tylko metody wyko-

${ }^{85}$ Tu za: B. Bell, A System of Surgery, Ed. Thomas \& Andrews, Boston 1791, s. 248-308.

${ }^{86}$ Tamże, s. 301.

87 R.I. Harris, The History and Development of Syme's Amputation, „Artificial Limbs" 1961, vol. VI, nr 1, s. 4-43.

${ }^{88}$ L. Baudens, Nouvelle Méthode des amputations, par le Dr Baudens... Premier mémoire. Amputation tibio-tarsienne, Ed. Balliere, Paris 1842.

${ }^{89}$ Tamże, ryc. III, br. paginacji.

90 Tamże, s. 7-23.

${ }^{91}$ Tamże, s. 15.

${ }^{92}$ Tu za: R. Singal, R. Pal Singal, A. Mittal, S. Sangwan, N. Gupta, Sir Astley Paston Cooper History, English Surgeon and Anatomist, „Indian J Surg”, January-February 2011, nr 73(1), s. 82-84.

${ }_{93} \mathrm{~S}$. Cooper, The first lines of surgery... Being an elementary work for students, and a concise book of reference for practitioners, Ed. Richard Philips, London 1807. 
nywania podstawowych zabiegów ${ }^{94}$. Trochę więcej miejsca przeznaczył na ów temat w swoim obszernym, liczącym ponad tysiąc stron $A$ Dictionary of Practical Surgery ${ }^{95}$, gdzie jeden $\mathrm{z}$ akapitów w dość rozbudowanym haśle „amputacje”" ${ }^{96}$, liczącym w sumie 70 stron, poświęcony był

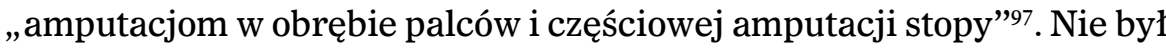
on obszerny, lecz podawał podstawowe dane oraz - co w tym kontekście zasługuje na szczególną uwage - nazwiska chirurgów, m.in. Roux i Langebecka, którzy również przeprowadzali podobne zabiegi. Przypuszczalnie ów brak szerszej prezentacji tej techniki operacyjnej w pracach chirurgów angielskich z przełomu XVIII i XIX w., a także dość spore rozproszenie danych bibliograficznych stały się jedną z przyczyn, dla których autorka książki uznała Jamesa Syme'a za twórcę nowej metody. Ale jak widać, wiedza na ten temat krążyła po Europie.

Jest jednak w tym tekście coś jeszcze. Otóż na tej samej stronie, gdzie autorka przyznaje pierwszeństwo wykonania amputacji w obrębie stawu skokowego właśnie Jamesowi Syme’owi, można przeczytać takie oto zdanie: „pogardzał prymitywnymi narzędziami takimi jak ręczna piła łańcuchowa"98. I znów nie wiem, co o tym wersie sądzić - czy to przypadkiem nie błąd tłumacza oraz późniejsza nieuwaga redakcji technicznej? Ale to również odstręczyło mnie od lektury. Dość mam opisu nabywania instrumentów chirurgicznych u przygodnych ślusarzy, jakim w połowie lat 90. „uraczył” swoich czytelników laureat nagrody Goncourtów z 1997 r. Patrick Rambaud ${ }^{99}$. Takiego narzędzia po prostu nie było. Warto pod tym kątem prześledzić skatalogowane zbiory Muzeum Historii Medycyny w Paryżu ${ }^{100}$ czy obszerną kolekcję połączoną z biblioteką Wellcome w Londynie ${ }^{101}$, a jeszcze lepiej Historii Wojskowej Służby Zdrowia w opactwie Val-de-Grâce ${ }^{102}$, które znajduje się w Paryżu.

Wykonując amputacje, chirurdzy posługiwali się najczęściej piłkami z łukiem rozporowym mocującym brzeszczot i usztywniającym

94 Tamże, s. 495-506.

95 S. Cooper, A Dictionary of Practical Surgery, Ed. Longman \& Hurst, London 1822.

${ }_{96}$ Tamże, s. 49-119.

97 Tamże, s. 116-119.

${ }^{98}$ L. Fitzharris, dz. cyt., s. 113.

${ }^{99}$ P. Rambaud, Le bataille Ed.Bernard Grasset Paris 1997, przekład polski: P. Rambaud, Bitwa, Finna, Gdańsk 2004.

${ }^{100} \mathrm{https} / / /$ paryz.pl/musee-d-histoire-de-la-medecine/ [dostęp: 14.11.2018].

${ }^{101} \mathrm{https} / /$ wellcomelibrary.org/collections/ [dostęp: 14.11.2018].

102 „Le Musée du Service de Santé des Armées au Val - de - Grâce”, Ed. AXPRO, Paris 1998. 


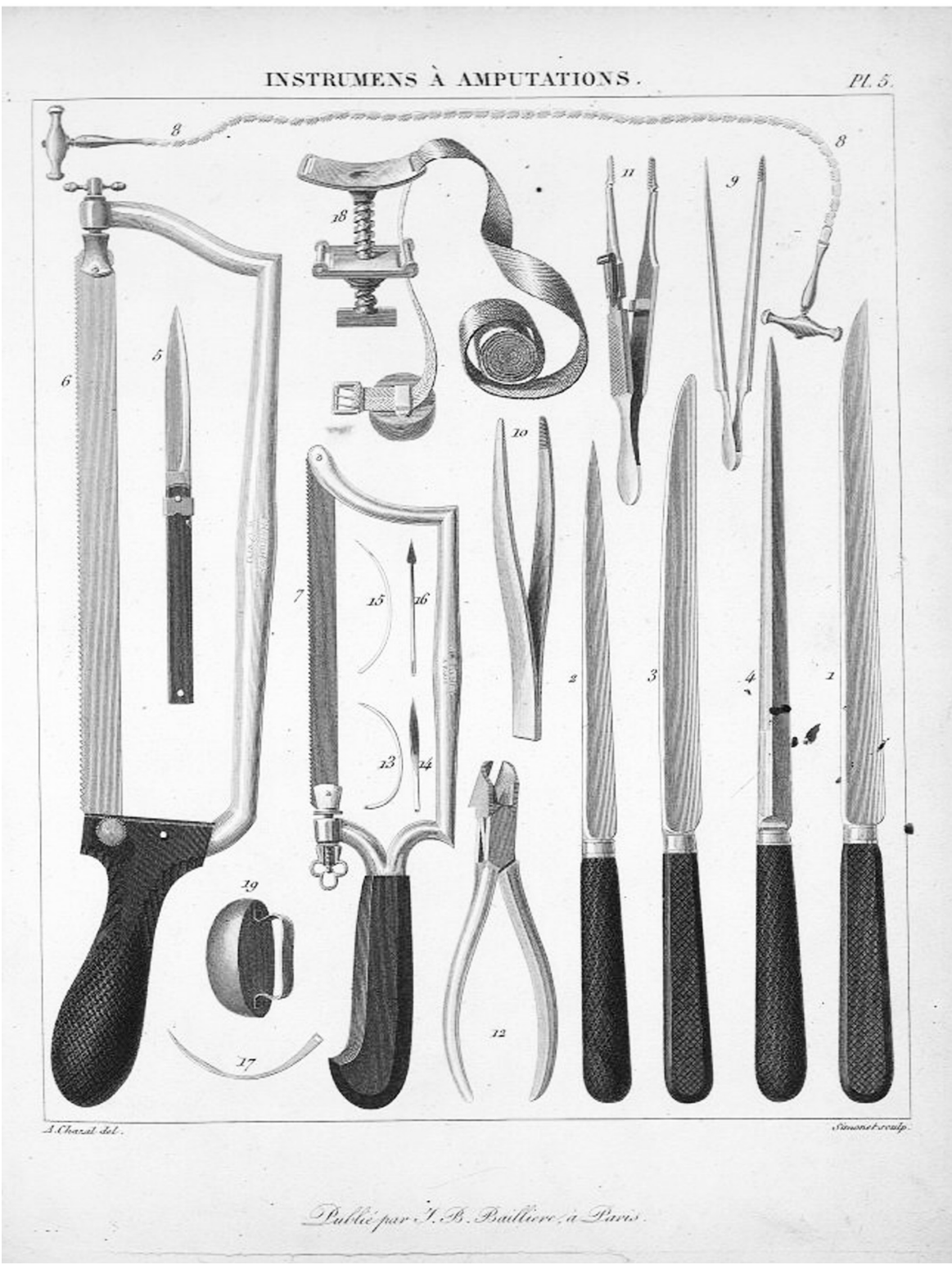

Ryc. 1. Instrumenty chirurgiczne z lat 20 . XIX w. Numer 8 - piłka lańcuszkowa według dr. Jeffreya

Źródło: dzięki uprzejmości kpt. Xaviera Tabbagha, naczelnego konserwatora Musée du Service de Santé des Armées Val-de-Grâce Paris. 
ostrze, a w warunkach polowych, przede wszystkim ze względu na wygodę i mniejszą wagę, szerszymi piłkami płaskimi. Posiadały one najczęściej drewniane rękojeści, często wykonane $z$ hebanu. Takie instrumenty prezentują na rycinach zamieszczonych w tekście swoich prac m.in. Benjamin Bell ${ }^{103}$ oraz Józef Czekierski ${ }^{104}$.

Owszem, istniała bardzo cienka i niezwykle ostra piłka, tzw. włosowa, zbliżona swoim wyglądem do tych, jakimi posługiwano się przy przecinaniu krat. Znaleźć ją można na planszach, które opublikował Alfred Velpeau w swojej pracy Nouveaux éléments de médecine opératoire ${ }^{105}$, stanowiącej swoisty atlas wybranych technik operacyjnych, dołączony do wielotomowego dzieła noszącego taki sam tytuł i opublikowanego w Paryżu w $1832 \mathrm{r}^{106}$ Instrument ten został wyszczególniony na planszy opatrzonej numerem $5^{107}$ i zatytułowanej Instrumenty stużace do amputacji jako pozycja ósma, a w załączonym przed nimi opisie można przeczytać „piłka przegubowa bądź łańcuszkowa według Dr. Jeffreya"108.

Z kolejnej planszy wynika, że było to narzędzie używane do resekcji główek kości w obrębie dystalnej części przedramienia, a także innych kości drobnych. O jej pierwszym wynalazcy, a raczej chirurgu, który zastosował ją do konkretnego zabiegu, również zapomniano, gdyż podobna piłka używana jest do tej pory przy trepanacjach czaszki i nosi nazwe piłki Gigliego, choć bywa też opisywana jako Olivecron ${ }^{109}$ bądź piłka drutowa ${ }^{110}$. Jej ponowny konstruktor czy też użytkownik, włoski położnik z drugiej połowy XIX w., mający na imię Leonardo, poczynając od 1894 r., używał jej do przecinania spojenia łonowego ${ }^{111}$. Instrument ten nadal funkcjonuje też $\mathrm{w}$ ortopedii, torakochirurgii (szczególnie $\mathrm{w}$ warunkach polowych) ${ }^{112}$, lecz przede wszystkim w medycynie weterynaryjnej ${ }^{113}$.

${ }^{103}$ B. Bell, A System of Surgery..., dz. cyt., plansze br. paginacji.

${ }^{104}$ J. Czekierski, Chirurgii..., dz. cyt., plansze po tekście br. paginacji.

${ }^{105}$ A. Velpeau, Nouveaux éléments de médecine opératoire / Atlas, J-B. Balliere, Paris 1832.

106 Tamże.

107 Tamże.

${ }_{108}$ Tamże, s. 9.

${ }_{109} \mathrm{Tu}$ za: opakowanie instrumentu. „Piłka chirurgiczna typ Olivecron produkcja Spółdzielnia Pracy Zrzeszenie Metalowców Pruszków k/W. ul Niecała 3”.

$110 \mathrm{http}: / /$ www.medipment.pl/ [dostęp: 10.11.2018].

111 J. Kubicki, Leonardo Gigli (1863-1907), „Ginekologia Praktyczna” 2003, nr 76, s. 46.

${ }^{112}$ M.K. Lehnart, E. Sativsky, B. Eastbridge, B. Eastridge, Combat Casualty Care: Lessons Learned from OEF and OIF, Borden Institute (U.S.) Government Printing Office, 2012, s. 719.

${ }^{113}$ https://sklep.sigmed.pl/preparacja-kosci/2538-pila-gigli.html [dostęp: 2.11.2018]. 
Pozostaje jeszcze pytanie, skąd się wzięło w tekście owo określenie „piła łańcuchowa”. Aż wstyd się przyznać, ale z Internetu, a konkretnie z „Google Translator”. Otóż po wpisaniu tam francuskiej nazwy instrumentu figurującej na planszy z atlasu Velpeau, czyli „scie articulee ou à chaînons du docteur Jeffrey"114, otrzymujemy taką właśnie odpowiedź: „piła przegubowa lub pilarka łańcuchowa”115. Tłumaczowi - a jest nim Łukasz Müller ${ }^{116}$ - wyraźnie brakowało rozeznania w temacie. Godzi się więc zacytować tu zdanie wybitnej znawczyni warsztatu translatorskiego, jaką jest Małgorzata Łukasiewicz: „oryginał jest tylko jeden jedyny, a wokół niego krąży widmowy orszak możliwych wersji przekładu"117.

Czwarta strona okładki zawiera coś jeszcze. Zdanie, z którego początkową frazą naprawdę trudno się pogodzić. Brzmi ono: „XIX-wieczni chirurdzy często niewykształceni a nawet niepiśmienni kroili swoich pacjentów, nie myśląc o odkażaniu narzędzi" ${ }^{118}$. Nie wiadomo, z kim tu wieść polemikę. Czy jest to opinia autorki, czy swoisty chwyt reklamowy, gdyż często od tego miejsca po zerknięciu na tytuł rozpoczyna się bliższy kontakt z książką. Myślę, że liczba zacytowanych prac powstałych tylko na przełomie XVIII i XIX w. powinna wystarczyć za komentarz. Chirurdzy jednak byli ludźmi wykształconymi. A jeśli - bo tego wykluczyć nie można - autorka bądź autor tych słów odnosił je do opinii wyrażonej przez Pierre'a François Percy'ego o młodych lekarzach $^{119}$, często studentach jeszcze, wcielanych w szeregi armii napoleońskiej, to najlepszym przykładem może być tutaj Jacques Lisfranc. Pierwszy raz na polach bitew niezwykle krwawej kampanii $1813 \mathrm{r}$. (a spieszył z pomocą rannym m.in. pod Lipskiem i Hanau) stanął jako dwudziestodwulatek ${ }^{120}$, również nie mając ukończonych wyższych stu-

${ }^{114}$ A. Velpeau, dz. cyt., s. 9.

$115 \mathrm{https} / /$ translate.google.pl/?hl=pl\#fr/pl/scie\%20articul\%C3\%A9e\%20ou\%20\%C3\%A0\% 20cha\%C3\%AEnons [dostęp: 4.11.2018].

${ }^{116}$ L. Fitzharris, dz. cyt., karta tytułowa.

117 Tu za: Lektor: Czytelnik do potęgi drugiej, „Tygodnik Powszechny”, nr 21(3541), 21 maja 2017, s. 67.

${ }^{118}$ L. Fitzharris, dz. cyt., czwarta strona okładki.

${ }^{119}$ H. Ducoulombier, Un chirurgien de la Grande Armee. Le baron Pierre-François Percy, Ed. Teissedre, Paris 2004, wprowadzenie, br. paginacji.

${ }^{120}$ Odnośnie do daty urodzin zachodzą tu pewne rozbieżności. L-P. Fischer podaje rok 1787 (tu za: L-P. Fischer, Jacques Lisfranc de Saint Martin 1787-1847, „Histoire de Sciences Medicales” 2005, T. XXXIX, nr 1, s. 17-26), encyklopedia „WhoName Dit" - 2.04.1790 (tu za: http://www.whonamedit.com/doctor.cfm/2572.html, dostęp: 10.11.2018). 
diów medycznych. A doskonałą, skonstruowaną w sposób niezwykle nowoczesny pracę napisał dwa lata później. Zwraca na to uwagę m.in. Jean-François Lemaire ${ }^{121}$.

Rzetelność historyka nauki wymaga, by dotrzeć do tych właśnie trochę zapomnianych i nieznanych szerszemu gronu nauczycieli wielkiego mistrza oraz „Napoleona chirurgii” ${ }^{122}$, którym w opinii autorki był James Syme. Oni utorowali drogę i przez to wyjątkowo zasłużyli na naszą pamięć. A od tłumacza - no cóż podobnego szacunku dla tekstu, by w owej i tak strasznej chirurgii czasów przed wprowadzeniem znieczulenia ogólnego nie „snuła się” jeszcze piła typowa dla tartaku.

${ }^{121}$ J-F. Lemaire, La medecine napoleonienne, Paris 2003.

${ }^{122}$ L. Fitzharris, dz. cyt., s. 112. 